\title{
MELIMEX, an experimental heavy metal pollution study: Effects of increased heavy metal loads on phytoplankton communities
}

\author{
By René Gächter and Antonín Máreš \\ Swiss Federal Institute for Water Resources and Water Pollution Control (EAWAG) at Swiss Federal \\ Institutes of Technology (ETH)
}

Manuscript received on 28 June 1979

\begin{abstract}
Long-term impacts of increased metal loading $(\mathrm{Hg}, \mathrm{Cu}, \mathrm{Cd}, \mathrm{Zn}$ and $\mathrm{Pb})$ on phytoplankton communities of large limno-corrals (diameter $12 \mathrm{~m}$, depth $10 \mathrm{~m}$ ) were studied. Increased metal concentrations initially lowered phytoplankton biomass, as well as species number and photosynthetic activity of phytoplankton. They caused changes in metal speciation and shifts in phytoplankton community structure, favoring less susceptible species. Although adaptation was not sufficient to completely prevent the metal-induced depression of photosynthesis, due to depressed zooplankton grazing, at the end of the experiment even higher phytoplankton densities were observed in the metal-loaded corrals than in the control.
\end{abstract}

\section{Introduction}

It is well documented that mercury, copper, cadmium, zinc and lead are able to inhibit growth and photosynthesis of algae, e.g. $[4,6,7,9,16,20,21,32,33,36,37$, 39]. It has been further demonstrated by several authors that inhibition depends not only on the concentration of the metal but is strongly affected by its chemical speciation $[1,10,18,31]$. Inhibition is thus influenced by $\mathrm{pH}$, alkalinity, concentration and chemical nature of organic and inorganic ligands and by the activity of suspended material, capable of sorbing free and complexed metal ions on their surfaces. Other metals in solution might either increase or decrease the toxic effect of the metal under consideration $[9,26,39]$. Metal toxicity further depends on phytoplankton density $[9,33]$, species composition $[6,8,15,17,32,39]$ and concentration of nutrients in the culture medium [34].

It is expected that in lakes with metal concentrations increased above a critical level there would primarily be a reduction in growth rates of the most sensitive species and thus shifts in their phytoplankton community structure, resulting in a dominance of the more resistent species. Experimental evidence supporting this hypothesis was given by Thomas and Seibert [35] and Kuiper [21] who demonstrated that in marine ecosystems a single dose of 5 or $10 \mu \mathrm{g} / 1$ of copper or $5 \mu \mathrm{g} / 1$ of mercury resulted in a change in phytoplankton species composition. Furthermore, in ex- 
periments with artificial streams Wuhrmann and Eichenberger [40] observed distinct shifts in periphyton community structure when metal concentrations were elevated by only $5 \times 10^{-8} \mathrm{M} \mathrm{Fe} / 1,2 \times 10^{-9} \mathrm{M} \mathrm{Mn} / 1,5 \times 10^{-9} \mathrm{M} \mathrm{Zn} / 1,5 \times 10^{-9} \mathrm{M} \mathrm{Co} / 1$, $5 \times 10^{-9} \mathrm{M} \mathrm{Mo} / 15 \times 10^{-9} \mathrm{M} \mathrm{Cu} / 1$. Qualitative and quantitative changes in food supply might also influence herbivorous and indirectly even carnivorous zooplankton or fish. Thus it is possible that in natural ecosystems, organisms of higher trophic levels become adversely affected at metal concentrations which in laboratory experiments, conducted with individuals or isolated populations, would exhibit no negative effects.

In summary, it might be concluded that the response of natural communities towards increased metal concentrations is hardly predictable and might vary from lake to lake depending on the existing community structure, its degree of eutrophication and other physicochemical properties mentioned above.

For running waters the following concentrations, expressed in $10^{-8} \mathrm{~mole} / \mathrm{l}$ are the

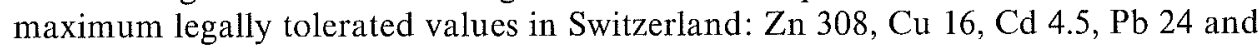
$\mathrm{Hg}$ 0.5. No such limits have yet been established for lakes. However based on shortterm experiments, which investigated the effect of increased metal concentrations on phytoplankton photosynthesis [9] it is to be expected that the phytoplankton of receiving lakes would be adversely affected if metal concentrations in the tributaries would reach the tolerated limits mentioned above.

Thus, this study was initiated with a twofold purpose

- to study in isolated watercolumns (diameter $12 \mathrm{~m}$, depth $10 \mathrm{~m}$ ) longterm effects of a legally maximum tolerated metal load on a lake's natural phytoplankton community and

- to provide background information for related papers concerning the impact of increased heavy metal load on zooplankton community structure and production [38], bottom fauna [22], bacterial activity [5], seasonal and spacial variation of metal concentrations, sorption and sedimentation of metals [2] and the chemical speciation of copper [3].

\section{Methods}

A more detailed description of experimental design has been given elsewhere [13]. To briefly summarize, in November 1976 three large limno-corrals (diameter $12 \mathrm{~m}$, volume $1,130 \mathrm{~m}^{3}$, extending from the lake surface to the sediments) were installed in Lake Baldegg, a highly eutrophic lake in central Switzerland. Since the environment within the enclosures, differs from that in the open lake in many respects (decreased turbulence and nutrient loading, shading), plankton populations were allowed to adapt to conditions within the limno-corrals before the experiment was started in April 1977. A system of four pumps, pumping water into and out of the corrals, yielded an average flow through rate of $11.5 \mathrm{~m}^{3} /$ day. Over the period of the study in the inflows of limno-corrals L1 and L2, metal concentrations were continuously elevated to approximately the legally tolerated limits mentioned above; in the inflow to the third limno-corral $\mathrm{C}$, which served as a control, concentrations equaled to lake ambient levels ( 5 to $20 \times 10^{-8} \mathrm{M} \mathrm{Zn} / 1,2 \times 10^{-8} \mathrm{M} \mathrm{Cu} / 1,1.5$ to $5 \times 10^{-10} \mathrm{M}$ $\mathrm{Cd} / 1,10^{-9} \mathrm{M} \mathrm{Pb} / 1$ and less than $\left.1 \times 10^{-10} \mathrm{M} \mathrm{Hg} / 1\right)$. 
Samples were collected in biweekly intervals at depths of $0,1,2.5,5,7.5 \mathrm{~m}$ with a PVC Niskin water sampler. The method suggested by SCOR [29] was used to determine concentrations of chlorophyll a in replicate mixed samples $(0,2.5$ and $5 \mathrm{~m}$ ). Changes of phytoplankton composition were monitored by inspection of Lugols' preserved mixed samples using an inverted microscope. Primary production was determined by the acid-bubbling method $[12,28]$. Samples from $0,1,2.5,5$ and $7.5 \mathrm{~m}$ were incubated in situ from $10 \mathrm{am}$ to $2 \mathrm{pm}$ in the water immediately outside the enclosure. Transparency was measured with a white Secchi disc (diameter $30 \mathrm{~cm})$. Zooplankton was collected with vertical net hauls $(8 \mathrm{~m}$ to lake surface, net aperture $300 \mu \mathrm{m}$ ) and zooplankton biomass was roughly estimated by determining the weight of freeze-dried samples. Metal concentration were measured using AAS techniques as described by Baccini [2].

In order to measure the concentration of macromolecular and ultrafilterable metal compounds, mixed near surface samples (sampling depths $0,1,2,3 \mathrm{~m}$ ) obtained from $\mathrm{L} 1$ and $\mathrm{L} 2(\mathrm{~L} 1, \mathrm{~L} 2)$ and from limno-corral C were filtered (pore size $0.45 \mu \mathrm{m}$ ) and concentrations of dissolved mercury, copper, cadmium, zinc and lead of sample $\mathrm{C}$ were adjusted to concentrations of dissolved metals measured in the L1, L2 sample. 51 of each sample were then subjected to ultrafiltration. After $4.91 \mathrm{had}$ passed the Amicon Diaflo UM-2 membrane, ultrafiltration was stopped and the concentration of $\mathrm{Cu}, \mathrm{Cd}, \mathrm{Zn}$ and $\mathrm{Pb}$ was measured in the $100 \mathrm{ml}$ residues. Knowing the metal concentration of the residue and of the original sample allows an estimate of the concentration of ultrafilterable and macromolecular species in the original sample [10].

In order to measure susceptibility of $\mathrm{L} 2$ and $\mathrm{C}$ plankton, phytoplankton collected with a $20 \mu \mathrm{m}$ net was resuspended in filtered lake water obtained from Lake Baldegg, spiked with increasing amounts of copper and zinc, respectively. To measure ${ }^{14} \mathrm{C}$ uptake rates, the samples were exposed during 24 hours in a rotating light thermostat at the temperature measured in the top layer of the corrals. After exposure they were treated as described by Gächter et al. [12].

\section{Results and discussion}

As a result of increased metal loading, concentrations of dissolved metals were distinctly higher in limno-corrals L1 and L2 than in the control, but due to sorption

Table 1. Concentration ranges of dissolved metals in the loaded limno-corrals (L1 and L2) and in the control (C) from June 1977 to June 1978. Figures indicate $10^{-8}$ mole $/$. n.d. $=$ not detectable.

Tabelle 1. Konzentrationsbereiche für gelöste Metalle in den metallbelasteten Behältern (L1 und L2) und in der Kontrolle (C) für die Periode Juni 1977 bis Juni 1978. Angaben in $10^{-8} \mathrm{Mol} / 1$. n.d. = nicht nachweisbar.

\begin{tabular}{lllllr}
\hline & $\mathrm{Hg}$ & $\mathrm{Cu}$ & $\mathrm{Cd}$ & $\mathrm{Zn}$ & $\mathrm{Pb}$ \\
\hline $\begin{array}{l}\text { Limno-corrals } \\
\text { L1 and L2 }\end{array}$ & $<0.04-0.08$ & $7-10$ & $1.5-2.0$ & $150-300$ & $2-4$ \\
Behälter L1 und L2 & & & & \\
$\begin{array}{l}\text { Limno-corral C } \\
\text { Behälter C }\end{array}$ & n.d. & $1-2$ & $0.02-0.1$ & $6-30$ & $0.1-0.2$ \\
\hline
\end{tabular}


by phytoplankton and periphyton, lower than in their tributaries. Whereas in the control they approximately equaled the ambient concentrations of the lake, in limno-corrals L1 and L2 they fluctuated in the ranges compiled in table 1. For more detailed information concerning variations of dissolved metal concentrations as well as the metal content of phytoplankton, see Baccini et al. [2] and Gächter et al. [14] A brief summary about chemical and biological character of Lake Baldegg has been made by Gächter [13].

\subsection{Effects of increased metal concentrations on phytoplankton biomass}

As a measure of phytoplankton biomass, chlorophyll concentration was determined in about biweekly intervalls. Figure 1 shows that the phytoplankton spring bloom had already passed its maximum before the experiment with increased metal loadings of enclosures L1 and L2 was started on 4 April 1977. From 19 April 1977 to April 1978, chlorophyll concentrations of L1 and L2 were significantly lower than those of the control, but in May and June 1978 they exceeded those of the control by approximately tenfold.

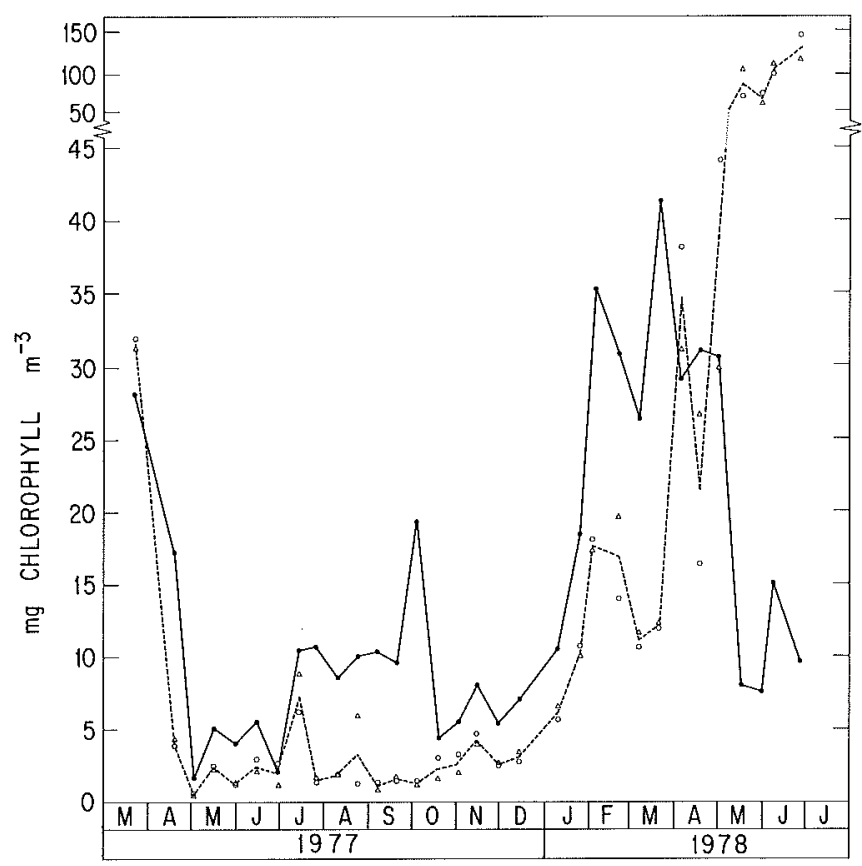

Figure 1. Seasonal variation of chlorophyll concentration in metal-loaded limno-corrals L1 $(O)$, L2 $(\triangle)$ and in the control $\mathrm{C}($ )

Abb. 1. Saisonale Veränderung der Chlorophyllkonzentration in den metallbelasteten Behältern L1 (O), L2 $(\triangle)$ sowie in der Kontrolle C $(\cdot)$. 


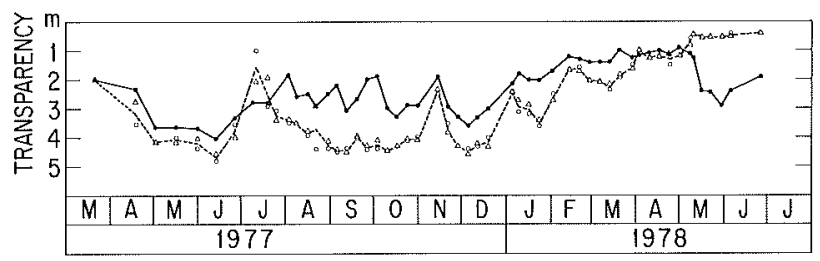

Figure 2. Seasonal variation of transparency in metal-loaded fimno-corrals L1 $(O)$, L2 $(\triangle)$ and in the control C (2).

Abb. 2. Saisonale Variation der Sichttiefen in den Behältern L1 (O), L2 ( $\triangle$ ) sowie in der Kontrolle C ( ).

Since transparency depends strongly on phytoplankton density, from April 1977 to March 1978 Secchi disc readings were as expected - with a few exceptions -, much higher in enclosures L1 and L2 than in C (see fig. 2). As expected from chlorophyll data, in May and June 1978 the transparency observed in limno-corral C was much higher than in limno-corrals L1 and L2.

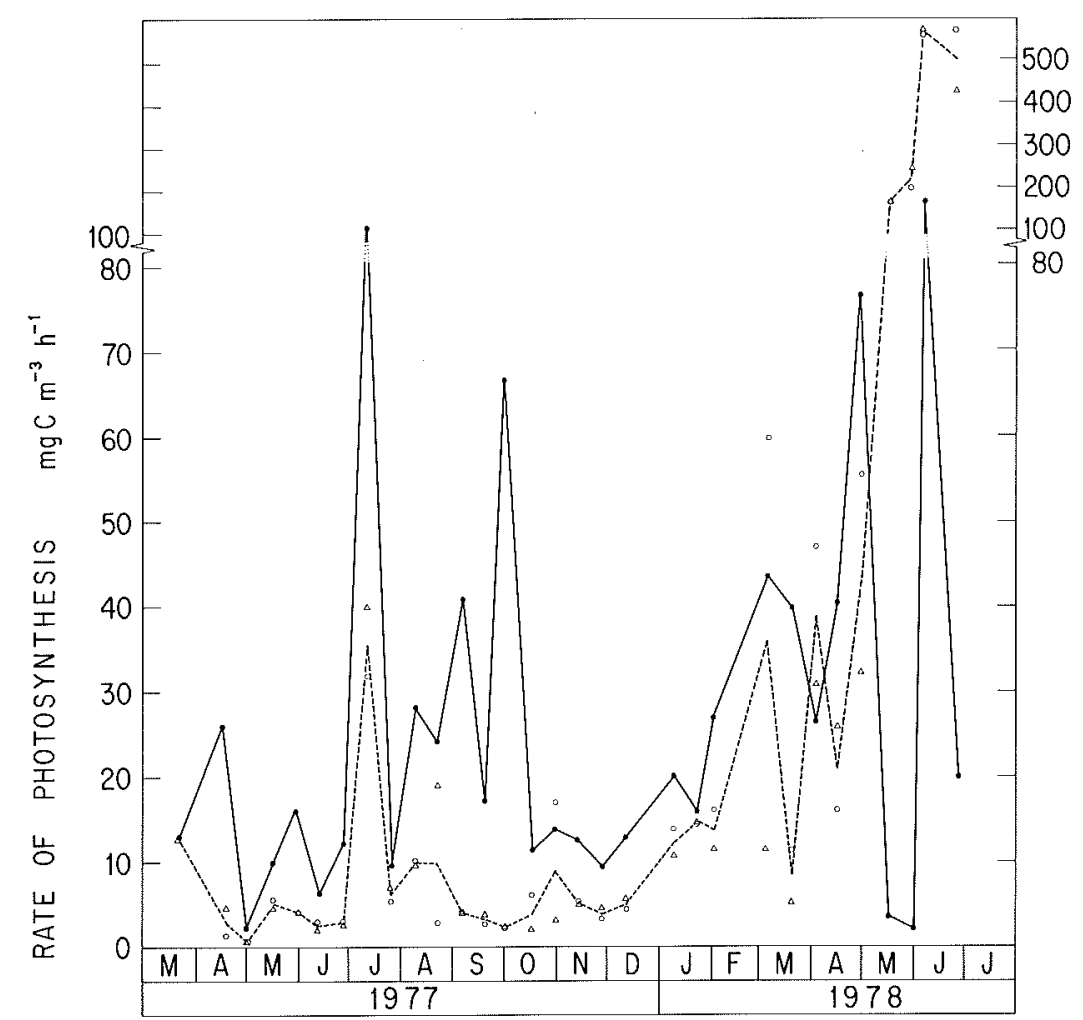

Figure 3. Seasonal variation of maximum observed rates of photosynthesis in metal-loaded limno-corrals $\mathrm{L} 1(\bigcirc), \mathrm{L} 2(\triangle)$ and in the control C (๑).

Abb.3. Saisonale Variation der unter optimalen Lichtbedingungen beobachteten Photosyntheseraten L1 $(\mathrm{O}), \mathrm{L} 2(\triangle)$ sowie in der Kontrolle C $(\bullet)$. 
Figure 3 shows rates of ${ }^{14} \mathrm{CO}_{2}$ uptake observed at optimum light intensity; that is at the lake surface or at a depth of $1 \mathrm{~m}$, depending on weather conditions. ${ }^{14} \mathrm{C}$ assimilation rates were clearly depressed in enclosures L1 and L2 from April 1977 to March 1978 but again, during the period of May/June 1978, primary production rates measured in the metal-loaded enclosures significantly exceeded those of the control.

Variations of phytoplankton concentration may be described by the following equation:

$$
\frac{\mathrm{d}[\mathrm{PC}]}{\mathrm{dt}}=[\mathrm{PC}](\mathrm{p}-1)
$$

Where PC is the concentration of organic carbon associated with phytoplankton, and $\mathrm{p}$ and 1 are time-dependent gross production and gross loss coefficients, respectively. $\mathrm{p}$ is species dependent and in addition is subject to variations of environmental conditions such as light, temperature, nutrient concentrations and concentration of toxicants as e.g. heavy metals. 1 is subject to sedimentation velocity, grazing rate and rate of autolysis. $p$ and 1 could not be measured directly, because there exists no method to separate phytoplankton carbon from organic carbon associated with other organisms (bacteria, zooplankton) or detritus, but as a first approximation it seems reasonable to assume that $\mathrm{p}$ and 1 are directly related to the assimilation number (production/chlorophyll, see fig.4) and zooplankton density (see fig. 5) as a measure of grazing losses.

At the beginning of the experiment, chlorophyll concentrations (fig. 1), transparency (fig. 2), rate of primary production (fig. 3), assimilation numbers (fig.4), zooplankton density (fig. 5) were equal in all three limno-corrals. This also holds for phytoplankton species composition as observed by direct microscopic inspection and indicated by equal $\mathrm{E}^{663} / \mathrm{E}^{480}$ ratios (fig. 6 ). Since the three water columns were separated from the lake already in November 1976 these observations suggest that during this preexperimental period $\mathrm{p}$ and 1 values were approximately equal in all corrals.

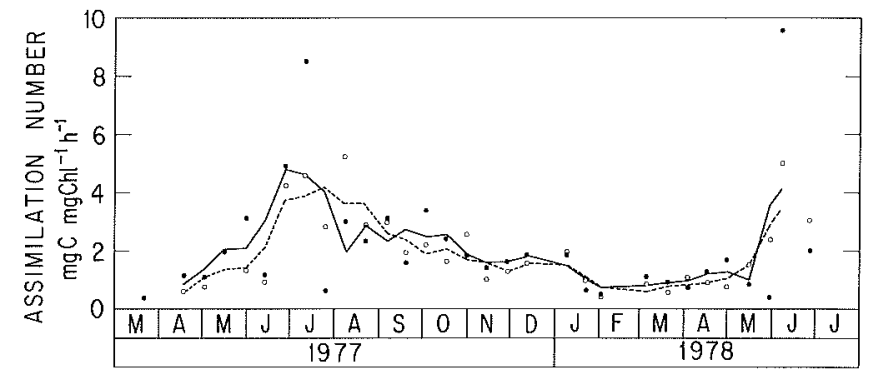

Figure 4. Assimilation numbers (= maximum observed rate of photosynthesis/chlorophyll concentration) estimated for metal-loaded enclosures L1, L2 [arithmetic mean (O)] and the control C ( ). Lines represent running means over three values for control ( ) and metal-loaded limno-corrals (----), respectively.

Abb.4. Assimilationszahlen (Kohlenstoffassimilationsrate/Chlorophyllkonzentration). Mittelwert für L1 und L2 (O). Beobachteter Wert in der Kontrolle C (-). Die Linien verbinden gleitende Mittel über drei Werte in der Kontrolle (- ${ }^{-}$) und den metallbelasteten Behältern (-----). 


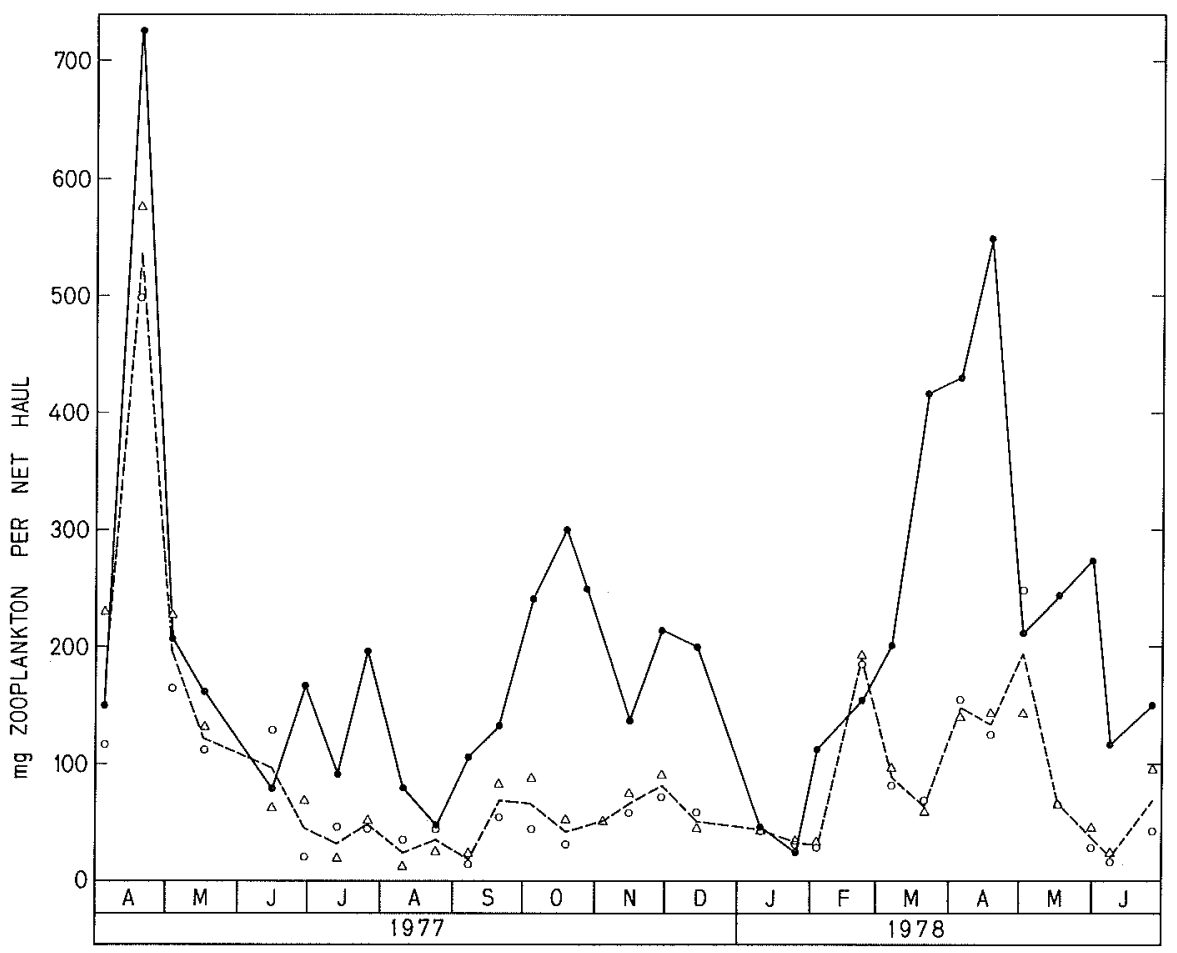

Figure 5. Seasonal variation of zooplankton standing stock (expressed as mg dry-weight collected per net haul) in limno-corrals $\mathrm{LI}(\mathrm{O}), \mathrm{L} 2(\triangle)$ and in the control C $(\bullet)$.

Abb. 5. Saisonale Variation der Zooplanktondichte, ausgedrückt in Milligramm (Trockengewicht) pro Netzzug ( $8 \mathrm{~m}$ bis Oberfläche) gefangenem Zooplankton. L1 $(\mathrm{O}), \mathrm{L} 2(\triangle)$ und Kontrolle C $(\odot)$.

Soon after the metal load of limno-corrals L1 and L2 became increased (April 1977), chlorophyll concentrations of $\mathrm{L}$ and $\mathrm{C}$ corrals diverged, suggesting smaller values for $(p-1)$ in limno-corrals L1 and L2 than in the control. This might be explained by the distinctly lower assimilation numbers, and hence $\mathrm{p}$ values in corrals $\mathrm{L} 1$ and L2 from April to the mid of July (see fig. 4).

From August 1977 to mid of March 1978 as compared to the control, chlorophyll concentrations in L1 and L2 were constantly lower by a factor of two to four. This observation, that phytoplankton biomass of $\mathrm{L}$ and $\mathrm{C}$ corrals no longer diverged implies approximately equal $(\mathrm{p}-1)$ values in $\mathrm{C}$ and $\mathrm{L}$ corrals. In fact, during this period assimilation numbers were about equal in $\mathrm{L}$ and $\mathrm{C}$ corrals with a slight tendency to somewhat lower values in $\mathrm{L} 1$ and L2. This slight difference may have been compensated by the simultaneously lower zooplankton grazing pressure (see fig. 5). As discussed below, this nearing of L1 and L2 assimilation numbers to those of the control might have resulted from shifts in phytoplankton species composition towards more metal resistent species, from changes in heavy metal speciation reducing metal toxicity or from higher nutrient concentrations in L1 and L2. The latter was due to the continuously depressed primary production and thus decreased 
nutrient uptake in the metal-loaded limno-corrals (see fig.3). A comparison of chlorophyll concentrations (fig. 1) with zooplankton biomass (fig. 5) indicates that in general, zooplankton biomass increased when chlorophyll concentration increased and decreased shortly after a preceding break down of phytoplankton standing crop. In spring 1978, for unknown reasons, this phytoplankton-zooplankton interaction became uncoupled. While in limno-corrals L1 and L2 chlorophyll concentrations increased practically steadily from March to June, zooplankton nearly completely collapsed in May. At the same time, assimilation numbers were higher in L1 and L2 than in the control. This coincidence of increased photosynthetic activity and reduced losses in $\mathrm{L} 1$ and $\mathrm{L} 2$ most probably was responsible for the drastic increase of chlorophyll concentrations in L1 and L2, up to values ten times as high as in the control.

In summary, it might be concluded that initially, increased metal concentrations depressed the photosynthetic activity of phytoplankton, causing lower chlorophyll concentrations in the metal-loaded limno-corrals. In a later phase, as shown below, shifts in phytoplankton species composition towards species less susceptible to metals and lowered zooplankton grazing completely counteracted the initial metalinduced depression of phytoplankton growth. Thus, on a long-term basis, metal concentrations which adversely affect the original phytoplankton organisms do not necessarily decrease primary production and thus the trophic state of a lake.

\subsection{Effects of increased metal concentrations on phytoplankton species composition}

In order to get some information about phytoplankton community structure, Margalef [25] suggested not only to measure chlorophyll a as a nonstructural property of a phytoplankton community but also to consider the general shape of the absorption spectrum of the pigment extract. This can be done by comparing extinction coefficients at two different wave lengths, $E^{\lambda 1}$ and $E^{\lambda 2}$. If the ratios $E^{\lambda 1} / E^{\lambda 2}$ of two samples are different, then it might be assumed that the extracted phytoplankton communities differed either in species composition or in their physiological state. According to figure 6 in enclosure L1 and L2, the ratios

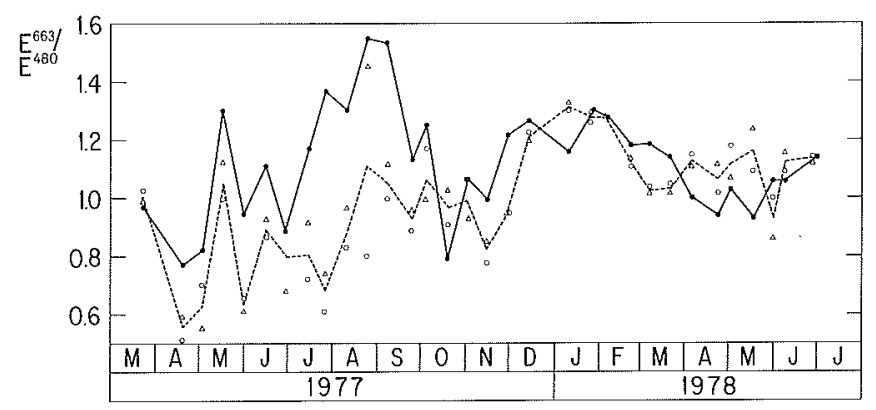

Figure 6. Ratio of light extinctions in the chlorophyll extract measured at 480 and $663 \mathrm{~mm} \mathrm{L1}(\mathrm{O})$, $\mathrm{L} 2(\triangle)$ and $\mathrm{C}(\mathrm{C})$.

Abb.6. Verhältnis der im Chlorophyllextrakt bei den Wellenlängen 480 und $663 \mathrm{~mm}$ gemessenen Extinktionen in $\mathrm{L} 1(\mathrm{O}), \mathrm{L} 2(\triangle)$ und $\mathrm{C}(\mathrm{\theta})$. 
$E^{663} / E^{480}$ were usually very close, and either distinctly higher or lower than in the control. Only on a very few occasions was the ratio observed in $\mathrm{C}$ between the values estimated for L1 and L2. This strongly suggests that species composition or physiological state of the phytoplankton communities were similar within L1 and L2 but different in $\mathrm{C}$.

When judging results of phytoplankton enumerations, it must be kept in mind that for technical reasons, results of plankton enumeration are less precise and reproducible than e.g. measurements of chlorophyll concentrations or primary production rates. In addition, samples taken in biweekly intervals cannot exactly show the development and decline of short-lived population peaks. Small phase shifts in the development of such pulses might temporarily simulate differences in phytoplankton species composition and density, which in fact might not be real. For this reason, for algae observed only occasionally or at a very low density, it is not possible to determine if they were affected by the increased metal loading. Nevertheless, phytoplankton enumeration has shown that the following 12 species or taxonomic groups occurred in the control mostly with higher densities than in the metal-loaded limno-corrals: Aphanizomenon flos aquae, Cyclotella spp., Fragillaria crotonensis, Fragillaria spp., Elakatothrix spp., Oocystis lacustris, Phacotus sp., Staurastrum sp., Cryptomonas ovata, Cryptomonas marsonit, Rhodomonas lacustris and microalgae. At the same time, only the following 7 groups were more abundant in the metalloaded limno-corrals than in the control: Various cyanophycea, various diatomea, Ankistrodesmus falcatus, Botryococcus braunii, Chlorella pyrenoidosa, Raphidium spp. and Schroederia setigera. Microalgae seemed to be growth-inhibited by increased metal concentrations during the first year of the experiment but compared to the control they developed higher densities in L1 and L2 in the spring of 1978. Other species or taxonomic groups were either not affected by the increased metal concentrations or effects could not be detected for reasons already mentioned. From April 1977 to June 197851 different phytoplankton species or taxonomic groups were identified, but the maximum species number observed in one sample was only $22^{1}$ ). The Shannon-Wiener [30] diversity index $\mathrm{H}$ is often used as a measure of the structural composition of a population. It increases as a function of species number, and the evenness of distribution of individuals among species or taxonomic groups present. $\mathrm{H}$ approaches $\mathrm{H}_{\max }$ if the number of individuals is equal for each species. The equitability $\mathrm{E}=\mathrm{H} / \mathrm{H}_{\max }$ (range 0 to 1 ) describes the eveness of allotment of individuals among the species.

Thomas and Seibert [35] observed a decrease in taxonomic diversity in enclosures treated with 10 and $50 \mu \mathrm{g} \mathrm{Cu} / 1$, but in another experiment, no significant differences were observed when copper concentration was increased by $10 \mu \mathrm{g} / \mathrm{l}$. Table 2 shows that the diversity index and equitability are subject to considerable temporal variation.

Results obtained from enclosures L1, L2 and C, indicate that a dominant effect of increased metal concentrations on diversity index or equitability cannot be observed. However there is a slight tendency towards higher species numbers in the control compared to metal-loaded limno-corrals. In $75 \%$ of the observations, species

1) More detailed results about plankton enumerations may be requested from the first author. 
Table 2. Species number, Shannon-Wiener diversity index and equitability.

Tabelle 2. Saisonale Veränderung der Artenhäufigkeit, des Diversitätsindexes und der Equitabilität.

\begin{tabular}{|c|c|c|c|c|c|c|c|c|c|}
\hline \multirow[t]{2}{*}{ Date } & \multicolumn{3}{|c|}{ Species number } & \multicolumn{3}{|c|}{ Diversity index } & \multicolumn{3}{|c|}{ Equitability } \\
\hline & $\mathrm{L} 1$ & $\mathbf{L} 2$ & $\mathrm{C}$ & $\mathrm{L} 1$ & $\mathrm{~L} 2$ & $\mathrm{C}$ & $\mathrm{L} 1$ & L2 & $\mathrm{C}$ \\
\hline 21. 3.77 & 15 & 13 & 15 & 2.1 & 2.2 & 2.1 & 0.55 & 0.61 & 0.55 \\
\hline 19. 4.77 & 13 & 14 & 16 & 2.4 & 2.9 & 2.2 & 0.66 & 0.76 & 0.56 \\
\hline 4. 5.77 & 18 & 5 & 16 & 2.1 & 1.9 & 1.3 & 0.49 & 0.84 & 0.32 \\
\hline 17. 5.77 & 7 & 6 & 8 & 1.7 & 1.7 & 1.4 & 0.60 & 0.67 & 0.47 \\
\hline 31. 5.77 & 9 & 10 & 10 & 1.6 & 2.9 & 2.4 & 0.50 & 0.90 & 0.72 \\
\hline 15. 6.77 & 9 & 5 & 13 & 0.9 & 1.3 & 2.2 & 0.27 & 0.57 & 0.59 \\
\hline 29.6 .77 & 9 & 7 & 18 & 0.1 & 1.5 & 3.1 & 0.43 & 0.54 & 0.74 \\
\hline 13. 7.77 & 4 & 6 & 7 & 1.6 & 2.3 & 1.2 & 0.80 & 0.87 & 0.42 \\
\hline 25. 7.77 & 5 & 5 & 12 & 0.3 & 0.9 & 2.4 & 0.14 & 0.04 & 0.67 \\
\hline 10. 8.77 & 11 & 9 & 5 & 0.1 & 0.3 & 0.2 & 0.03 & 0.08 & 0.09 \\
\hline 24. 8.77 & 12 & 4 & 14 & 0.2 & 0.0 & 1.9 & 0.07 & 0.00 & 0.51 \\
\hline 7. 9.77 & 4 & 2 & 10 & 0.1 & 0.1 & 1.6 & 0.05 & 0.15 & 0.47 \\
\hline 20. 9.77 & 10 & 15 & 18 & 1.4 & 1.8 & 2.8 & 0.42 & 0.47 & 0.67 \\
\hline 4.10 .77 & 12 & 14 & 15 & 2.4 & 2.2 & 2.3 & 0.68 & 0.58 & 0.59 \\
\hline 19.10 .77 & 20 & 10 & 12 & 2.7 & 2.3 & 1.2 & 0.64 & 0.69 & 0.32 \\
\hline 2.11 .77 & 11 & 11 & 10 & 1.9 & 2.8 & 2.1 & 0.56 & 0.80 & 0.62 \\
\hline 15.11 .77 & 10 & 16 & 17 & 2.3 & 2.0 & 0.8 & 0.69 & 0.49 & 0.19 \\
\hline 29.11 .77 & 9 & 7 & 9 & 2.4 & 1.8 & 2.4 & 0.76 & 0.64 & 0.76 \\
\hline 14.12 .77 & 14 & 14 & 8 & 2.7 & 2.6 & 0.5 & 0.70 & 0.68 & 0.18 \\
\hline 10. 1.78 & 14 & 13 & 17 & 2.8 & 2.7 & 2.8 & 0.73 & 0.74 & 0.68 \\
\hline 25. 1.78 & 19 & 16 & 20 & 1.4 & 2.7 & 1.3 & 0.34 & 0.67 & 0.29 \\
\hline 3. 2.78 & 18 & 20 & 16 & 1.5 & 2.4 & 1.3 & 0.36 & 0.54 & 0.33 \\
\hline 7. 3.78 & 15 & 17 & 19 & 2.3 & 2.3 & 0.9 & 0.57 & 0.56 & 0.21 \\
\hline 21. 3.78 & 16 & 14 & 20 & 1.2 & 1.4 & 1.9 & 0.30 & 0.37 & 0.44 \\
\hline 5. 4.78 & 17 & 16 & 17 & 2.3 & 2.0 & 2.4 & 0.57 & 0.50 & 0.60 \\
\hline 2. 5.78 & 14 & 14 & 14 & 1.8 & 1.4 & 2.6 & 0.47 & 0.37 & 0.67 \\
\hline 31. 5.78 & 12 & 10 & 15 & 2.1 & 1.0 & 0.9 & 0.58 & 0.30 & 0.22 \\
\hline 9. 6.78 & 12 & 22 & 9 & 0.7 & 1.4 & 1.4 & 0.20 & 0.30 & 0.44 \\
\hline
\end{tabular}

The student ' $A$ ' test yields significant differences $(p<0.05)$ between species number of limno-corrals $L 2$ and $C$. Species number of $L 1$ and $C$ as well as diversity indices and values of equitability of $L 1, L 2$ and $C$ are not statistically different from eachother.

number of the control exceeded that of L 2 but only in $21 \%$ of the events the opposite was observed. When comparing species numbers observed in $\mathrm{C}$ and $\mathrm{Ll}$, the corresponding values are 61 and $18 \%$. This tendency to lower species numbers in the metal-treated enclosures did not result in a systematic depression of diversity indices since, as shown in figure 7 , the diversity index depends strongly on the equitability but only weakly on the species number.

To briefly summarize: Increased metal concentrations caused shifts in phytoplankton species composition, and in general the number of species observed in metalloaded limno-corrals was lower than in the control. This depression of species number however did not result in a systematic depression of the Shannon-Wiener diversity index since this index is much more affected by the evenness of allotment of individuals among the species than by the absolute number of different species observed in each sample. 

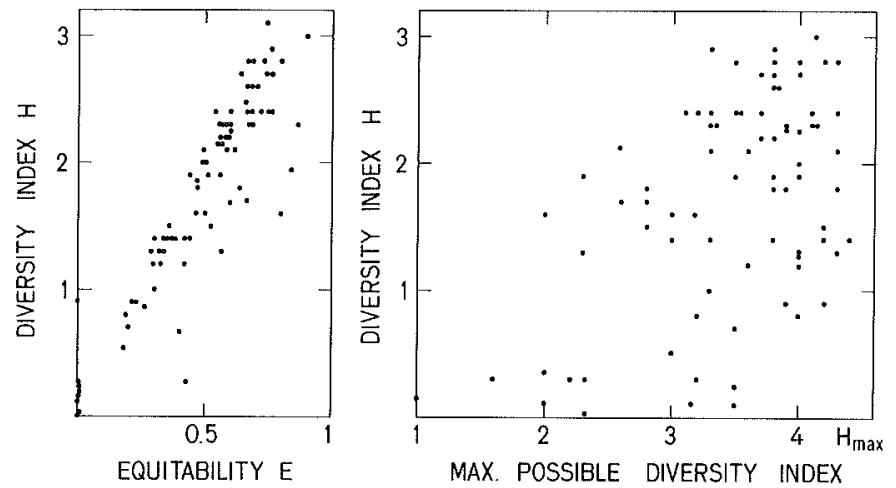

Figure 7. Diversity index as a function of equitability $\mathrm{E}$ and maximum possible diversity $\mathrm{H}_{\max }$. Abb.7. Beobachteter Diversitätsindex in Abhängigkeit von Equilibilität und dem bei der beobachteten Artenzahl maximal möglichen Diversitätsindex.

Susceptibility of $\mathrm{L} 2$ and $\mathrm{C}$ plankton towards copper and zinc is compared in figure 8 showing relative ${ }^{14} \mathrm{CO}_{2}$-assimilation rates $\left({ }^{14} \mathrm{CO}_{2}\right.$-assimilation rate in lake water without additional metals $=100 \%$ ) of $\mathrm{L} 2$ and $\mathrm{C}$ plankton as a function of either copper or zinc concentration in the medium. On eight occasions, L2 plankton was found to be less susceptible, and on two occasions more susceptible towards copper than $\mathrm{C}$ plankton. On two occasions no differences occurred. Zinc exhibited a similar result, i.e. L2 plankton was six times less susceptible and two times more susceptible than $\mathrm{C}$ plankton and on three occasions no obvious differences were observed.

These results might be interpreted in the following way: In the course of a year, phytoplankton communities are subject to continuous changes from a quantitative as well as from a qualitative point of view. This succession is most probably the result of many simultaneously occurring variations of environmental conditions. Phytoplankton depends on abiotic factors, such as temperature, incident light, concentration and speciation of nutrients and inhibitors, mixing and sedimentation as well as on biotic factors such as e.g. grazing, infection by parasites, production and decomposition of growth promoting and inhibiting organic compounds. $\mathrm{Ob}-$ viously the resulting phytoplankton population is adapted to actual environmental conditions. This means that species which momentarily profit the most from growthpromoting factors and which suffer the least from growth inhibiting factors will develop the best and reach the highest densities. If, in an ideal experiment, it would be possible to increase the metal concentration and keep all other regulating factors exactly at the level of the control, then, phytoplankton grown in the metal-polluted system would always be expected to be less susceptible to heavy metals than the control population. In the MELIMEX experiment however, metal loaded and control media differed not only in their metal content, but due to reduced primary production in $\mathrm{L} 1$ and $\mathrm{L} 2$ also in $\mathrm{pH}$, alkalinity and concentration of inorganic nutrients. Further, as demonstrated with amino acids [23] they differed in composition and concentration of organic compounds, as well as in density and species composition of zooplankton and thus in grazing pressure, as shown by Urech [38]. 

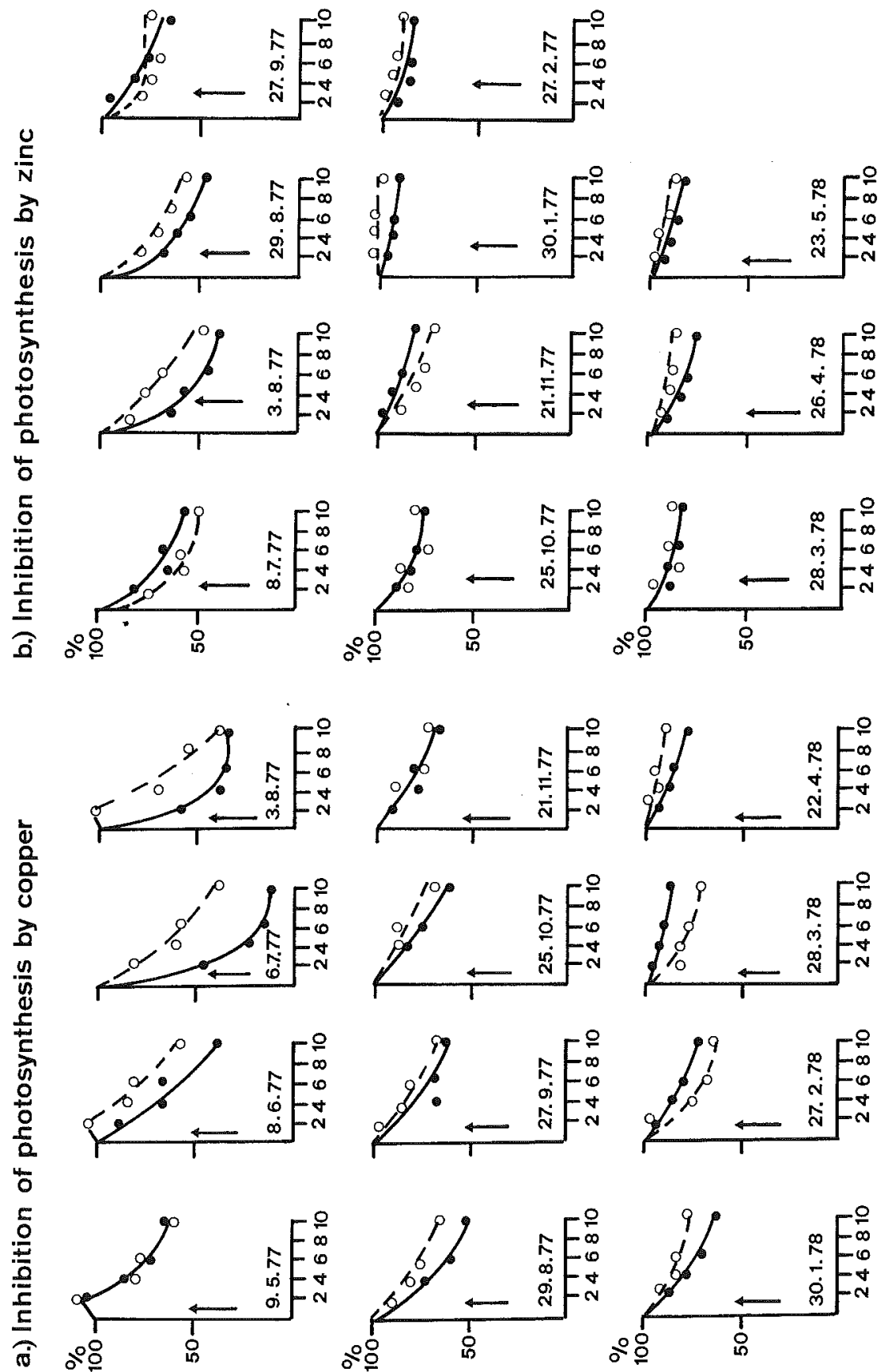

Figure 8. Depression of photosynthesis by copper and zinc for phytoplankton collected from the control (-) and limno-corral L2 (O---O), respectively. Arrows indicate actual metal concentrations in limno-corral L2. Figures on the X-axis indicate $10^{-7} \mathrm{~mole} / \mathrm{l}$ for copper and $10^{-6} \mathrm{~mole} / \mathrm{l}$ for zinc experiments.

Abb.8. Verminderung der Photosyntheseleistung des L-Planktons $(\mathrm{O}---\mathrm{O})$ und C-Planktons

(-) durch Kupfer und Zink. Angaben für Cu $10^{-7} \mathrm{Mol} / \mathrm{l}$, für $\mathrm{Zn} 10^{-6} \mathrm{Mol} / \mathrm{l}$. Pfeile bezeichnen die im Filtrat von L2 gemessenen Metallkonzentrationen. 
Consequently differences in the phytoplankton community structure cannot be explained exclusively on the basis of a direct effect of different metal concentrations. At least temporarily other factors mentioned might partly be responsible for observed differences in heavy metal susceptibilities. This might explain why phytoplankton collected from limno-corrals L1 and L2 was not always more resistant towards heavy metals than plankton obtained from the control.

In this context it is noteworthy that on only one occasion (30.1.78) adaption of L2 plankton to the increased metal concentrations was sufficient to prevent depression of photosynthesis at the zinc concentrations occurring in L2. It follows that in spite of qualitative shifts in phytoplankton towards more resistant species, photosynthesis of $\mathrm{L} 2$ plankton was depressed most of the time by the elevated zinc concentration. Depression of photosynthesis by zinc (see fig. 8) is the same order of magnitude $(5-30 \%)$ as the observed reduction of assimilation numbers (see fig.4). It might therefore be concluded, that the elevated concentrations of zinc are mainly responsible for the observed depression of photosynthesis in limno-corrals L1 and L2.

\subsection{Effects of increased metal concentrations on the spectrum of dissolved or colloidal organic ligands}

In addition to changes in phytoplankton community structure, phytoplankton also could avoid metal stress partly or completely by changing heavy metal speciation, thus reducing their physiological availability and hence toxicity. Figure 9 shows in fact that increased metal concentrations caused shifts in the spectrum of free dissolved amino acids and thus illustrates the possibility of metal-induced changes in a lake's spectrum of dissolved organic compounds. Gächter et al. [10] recently gave evidence that dissolved macromolecular or colloidal substances present in lake water are able to complex copper and to reduce its toxicity. Thus, the capability of filtered samples to form macromolecular and hence physiologically nonavailable metal complexes was investigated.

Ratios of macromolecular (MM) to ultrafiltrable (UF) metal species, indicate clearly (table 3) that copper exhibits a much higher affinity to macromolecular or colloidal substances than does cadmium, zinc or lead. Thus, although these substances control the availability of copper to a considerable extent, they seem to be relatively unimportant in regulation of cadmium, zinc and lead availability. Furthermore, it can be deduced from table 3 that in general MM/UF ratios for copper and lead were higher in samples obtained from limno-corrals L1 and L2 than in samples originating from the control. In order to explain this phenomenon, two possible causes may be considered:

- increased capacity to form macromolecular complexes in limno-corrals $\mathbf{L} 1$ and L2 and (or)

- depressed capacity to form ultrafilterable complexes in limno-corrals L1 and L2.

Differences in complex formation between samples obtained from metal-loaded limno-corrals and from the control might be explained by differences in the nature of organic ligands or by different $\mathrm{pH}$ values owing to depressed photosynthesis in 

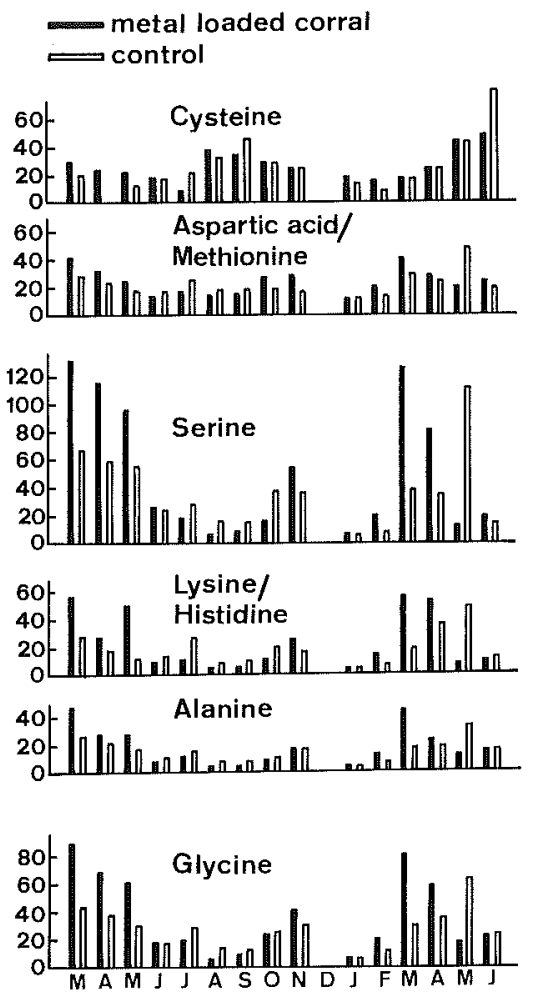

Figure 9. Seasonal variation of dissolved free amino acids in metal-loaded (light bars) and control limnocorral (dark bars).

Abb.9. Saisonale Variation der freien gelösten Aminosäuren in metallbelasteten Behältern (leere Balken) und in der Kontrolle (ausgefüllte Balken).

Table 3. Temporal variation of MM/UF ratios in limno-corrals L1, L2 and C, respectively.

Tabelle 3. Saisonale Veränderung des MM/UF-Verhältnisses in L und C. MM und UF bedeuten Konzentrationen von makromolekularen und ultrafiltrierbaren Metallspezies.

\begin{tabular}{|c|c|c|c|c|c|c|c|c|}
\hline \multirow[t]{2}{*}{ Date } & \multicolumn{2}{|l|}{ Copper } & \multicolumn{2}{|l|}{ Cadmium } & \multicolumn{2}{|l|}{ Lead } & \multicolumn{2}{|l|}{ Zinc } \\
\hline & L1, L2 & $\mathrm{C}$ & $\mathrm{L} 1, \mathrm{~L} 2$ & $\mathrm{C}$ & $\mathrm{L} 1, \mathrm{~L} 2$ & $\mathrm{C}$ & $\mathrm{L} 1, \mathrm{~L} 2$ & $\mathrm{C}$ \\
\hline 25.4 .77 & 0.4 & 0.8 & 0.08 & 0.08 & - & - & 0.24 & 0.31 \\
\hline 20.6 .77 & 1.0 & 1.0 & 0.08 & 0.08 & 0.12 & 0.15 & 0.24 & 0.22 \\
\hline 15. 8.77 & 9.1 & 1.0 & 0.12 & 0.06 & 0.17 & 0.06 & 0.27 & 0.22 \\
\hline 12. 9.77 & 3.2 & 2.4 & 0.11 & 0.06 & 0.23 & 0.06 & 0.11 & 0.13 \\
\hline 10.10 .77 & 2.0 & 1.1 & 0.11 & 0.05 & 0.11 & 0.05 & 0.16 & 0.09 \\
\hline 8.11 .77 & 5.9 & 3.6 & 0.27 & 0.27 & 0.22 & 0.13 & 0.14 & 0.06 \\
\hline 5.12 .77 & 6.5 & 2.2 & 0.30 & 0.31 & 0.50 & 0.36 & 0.16 & 0.12 \\
\hline 16. 1.78 & 1.0 & 0.7 & 0.27 & 0.67 & 0.67 & 0.58 & 0.10 & 0.09 \\
\hline 13. 2.78 & 5.7 & 1.1 & 0.29 & 0.17 & 0.63 & 0.35 & 0.13 & 0.03 \\
\hline 13. 3.78 & 1.7 & 0.8 & 0.16 & 0.16 & 0.16 & 0.10 & 0.08 & 0.09 \\
\hline 13. 4.78 & 3.9 & 3.2 & 0.38 & 0.29 & 0.38 & 0.20 & 0.15 & 0.08 \\
\hline
\end{tabular}

MM/UF ratios are statistically different in limno-corrals L1, L2 and C $(\mathrm{p}<0.05)$ for copper and lead but not for cadmium and zinc. 


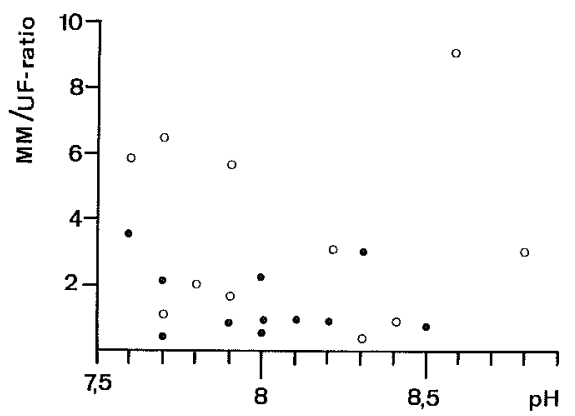

Figure 10. MM/UF ratios plotted vs. $\mathrm{pH}(-)$ control (O) L1, L2.

Abb. 10. Verhältnis von makromolekularen zu ultrafiltrierbaren Kupferspezies in Abhängigkeit vom pHWert. Kontrolle (-), Mischproben aus L1 und L2 (O).

limno-corrals L1 and L2. To check the influence of $\mathrm{pH}$ on complex formation and thus the MM/UF ratio, in figure $10 \mathrm{MM} / \mathrm{UF}$ ratios were plotted vs. $\mathrm{pH}$ values.

Obviously variations of MM/UF ratios cannot be explained, only on the basis of variations of $\mathrm{pH}$. Thus, the results in table 3 strongly suggest that

- the composition of complex forming substances was variable with time and

- the spectrum of ligands was different in metal-loaded and control limno-corrals.

Since water residence time of Lake Baldegg is in the order of 6 years, the concentration of organic ligands would be expected to be rather constant if they would be mainly of allochthonous nature. Thus these results indicate that organic substances able to complex copper are at least partly of autochthonous nature and either their production or destruction is subject to the metal concentration of the water. Determining complexing capacity of the total organic ligands, Baccini et al. [3] found no systematic differences in $\mathrm{L}$ and $\mathrm{C}$ limno-corrals. They further estimated equal complex formation constants for macromolecular and ultrafilterable ligands. This suggests that although MM/UF ratios and hence metal speciation, were different in $\mathrm{L}$ and $\mathrm{C}$ limno-corrals, the total activity of organic MM plus UF ligands was essentially identical in the metal-loaded and control limno-corrals. Thus the observed changes in the spectrum of organic ligands most probably did not result in a reduction of metal ion activities and hence physiological availability and toxicity of metals.

\section{Summary and conclusions}

Long-term impacts of increased metal loading on phytoplankton community of large limno-corrals were investigated. It was found that increasing the metal concentration of running waters, up to the maximum legally tolerated limits,

- affects adversely the original phytoplankton of the receiving lakes, primarily by depression of its photosynthetic activity,

- reduces phytoplankton species number and

- causes major shifts in phytoplankton community structure towards populations less susceptible to heavy metals. 
However, in spite of this adaption of the metal-loaded phytoplankton, adaption was not sufficient to prevent depression of photosynthesis by zinc at the concentrations occurring in the metal-loaded limno-corrals. Nevertheless, at the end of the experiment, due to simultaneously depressed zooplankton grazing even higher chlorophyll concentrations were observed in the metal-loaded corrals than in the control.

Increased metal concentrations also affected the composition of organic ligands. These changes however seemed not to influence the ionic activity of metals and hence their physiological availability.

Briefly summarized, it might be concluded that on a long-term basis an increase of the metal loading up to the legally tolerated limits would cause changes in the phytoplankton community structure. However it would not generally reduce primary production and hence the trophic state of a lake, as could be expected from short-term experiments.

A main conclusion of these observations is that the metal-concentration limits set for flowing waters are not low enough to prevent adverse effects in the receiving lakes, and that especially the limit set for dissolved zinc $\left(3.1 \times 10^{-6}\right.$ mole $\left./ 1\right)$ should be lowered.

\section{ZUSAMMENFASSUNG}

Es war das Ziel dieser Arbeit, Langzeitwirkungen einer erhöhten Schwermetallbelastung auf das Phytoplankton von Seen zu untersuchen. Zu diesem Zweck wurden im Baldeggersee drei Wasserkörper von rund $1100 \mathrm{~m}^{3}$ Volumen vom übrigen See abgetrennt. Zwei davon ( $\left.\mathrm{L} 1 \mathrm{und} \mathrm{L} 2\right)$ wurden kontinuierlich mit Schwermetallen belastet. Der dritte Behälter (C) diente als Kontrolle und wurde mit grobfiltriertem Baldeggerseewasser gespiesen. Die Metallkonzentrationen im Zulauf zu den metallbelasteten Behältern betrugen etwa $16 \times 10^{-8} \mathrm{M} \mathrm{Cu} / \mathrm{l}, 308 \times 10^{-8} \mathrm{M} \mathrm{Zn} / 1,4,5 \times 10^{-8} \mathrm{M} \mathrm{Cd} / 1,0,5 \times 10^{-8} \mathrm{M} \mathrm{Hg} / 1$ und $24 \times 10^{-8} \mathrm{M} \mathrm{Pb} / 1$ und entsprachen damit den in der Verordnung über Abwassereinleitungen fixierten Zielvorstellungen für Fliessgewässer.

Abb. 1 und 3 zeigen, dass die erhöhten Metallkonzentrationen in L1 und L2 anfänglich eine Reduktion der Primärproduktion und damit eine Verminderung der Chlorophyllkonzentration bewirkten. Als Folge davon wurden in den belasteten Behältern deutlich erhöhte Sichttiefen beobachtet. Gleichzeitig bewirkte die erhöhte Metallbelastung eine deutliche Herabsetzung der Zooplanktondichte und damit des GrazingDruckes (siehe Abb.5) sowie eine qualitative Verschiebung im Artenspektrum des Phytoplanktons: 12 Arten oder taxonomische Gruppen traten in der Kontrolle meistens mit deutlich höheren Dichten auf als in den metallbelasteten Behältern. Aphanizomenon flos aquae, Cyclotella spp., Fragillaria crotonensis, Fragillaria spp., Elakatothrix spp., Oocystis lacustris, Phacotus sp., Staurastrum sp., Cryptomonas ovata, Cryptomonas marsonii, Rhodomonas lacustris und Mikroalgen. Nur 7 Gruppen verzeichneten häufig höhere Individuendichten in den metallbelasteten Behältern als in der Kontrolle, nämlich verschiedene Cyanophyceen, verschiedene Diatomeen, Ankistrodesmus falcatus, Botryococcus braunii, Chlorella pyrenoidosa, Raphidium spp. und Schroederia setigera.

Wie aus Abb. 8 entnommen werden kann, reagierte das Phytoplankton der metallbelasteten Behälter meist deutlich weniger empfindlich auf Erhöhungen der Kupfer- und Zinkkonzentrationen als das Plankton der Kontrolle. Trotz dieser offensichtlichen Adaptation an die erhöhten Metallkonzentrationen wurde aber die Photosyntheseleistung des Planktons durch die in den metallbelasteten Behältern auftretenden Zinkkonzentrationen meistens gehemmt.

Neben der beobachteten Artenverschiebung des Phytoplanktons bewirkten die erhöhten Metallkonzentrationen auch eine Veränderung in der Zusammensetzung der im Wasser gelösten oder kolloidalen organischen Liganden sowie der im Wasser gelösten freien Aminosäuren (siehe Abb.9). Aufgrund der Untersuchungen von Baccini et al. [3] bewirkte diese Veränderung in der Metallspeziierung allerdings keine Herabsetzung der physiologischen Verfügbarkeit der Metalle. 
Im Mai 1978 verursachte ein zeitliches Zusammentreffen von erhöhter Photosyntheseaktivität des Phytoplanktons und praktisch vollständigem Zusammenbruch des Zooplanktons in L1 und L2 ein Ansteigen der Chlorophyllkonzentration in den metallbelasteten Behältern auf rund den 10fachen Wert der Kontrolle.

Kurz zusammengefasst kann aus den vorliegenden Resultaten gefolgert werden, dass eine Erhöhung der Metallbelastung eines Sees auf den gesetzlich maximal tolerierten Grenzwert

- qualitative Verschiebungen im Phytoplankton-Artenspektrum sowie im Spektrum von gelösten oder kolloidalen organischen Substanzen zur Folge hätte,

- zu weniger metallempfindlichen Phytoplanktonpopulationen führen würde (Selektion, Adaptation),

- auch das Zooplankton schädigen würde,

- aber über längere Zeit betrachtet nicht, wie das aufgrund von Kurzzeitexperimenten erwartet werden könnte, zu einer generellen Reduktion der Primärproduktion und damit des Trophiegrades führen würde.

Aufgrund der vorliegenden Daten kann daher gefolgert werden, dass die für Fliessgewässer festgesetzten Toleranzlimiten eine Schädigung des Planktons von Unterliegerseen nicht auszuschliessen vermögen und dass vor allem die Toleranzlimite für Zink $\left(3,1 \times 10^{-6} \mathrm{Mol} / \mathrm{l}=200 \mu \mathrm{g} / \mathrm{l}\right)$ tiefer angesetzt werden sollte.

\section{RÉSUMÉ}

Dans des modèles de lacs, cylindres de $12 \mathrm{~m}$ de diamètre et de $10 \mathrm{~m}$ de profondeur, on a étudié pendant une année l'effet prolongé d'une charge élevée de métaux lourds sur une population naturelle de phytoplancton.

Les concentrations élevées de métaux provoquaient, au début, une diminution de la biomasse de phytoplancton, du nombre d'espèces observées et de l'activité de la photosynthèse du phytoplancton. Elles provoquent d'ailleurs un changement dans la spécification des métaux et dans la composition qualitative du phytoplancton.

Malgré qu'au cours de l'expérience, l'adaptation observée du phytoplancton ne suffisait pas pour éviter complètement la diminution de l'activité de la photosynthèse induite par les métaux, on a observé, à la fin de l'expérience, une densité plus élevée du phytoplancton dans les modèles de lac chargés, que dans le contrôle, grâce à une diminution simultanée du zooplancton «herbivore».

\section{ACKNOWLEDGMENTS}

The authors wish to thank Dieter Imboden and Joan Davis for helpful discussions and William H. Thomas and Paul T. S. Wong for critically reviewing the manuscript. Phytoplankton identification and enumeration were made by A. Schwander, Sempach. The assistance of A. Widmer, typist, and H. Bolliger, draftswoman, is gratefully acknowledged.

\section{REFERENCES}

1 Anderson, D.M., and Morel, F.M.M.: Copper sensitivity of Gonyaulax tamarensis. Limnol. Oceanogr. 22, 283-295 (1978).

2 Baccini, P., Ruchti, J., Wanner, O., and Grieder, E.: MELIMEX, an experimental heavy metal pollution study: Regulation of trace metal concentrations in limno-corrals. Schweiz. Z. Hydrol. 41, 202-227 (1979).

3 Baccini, P.: MELIMEX, an experimental heavy metal pollution study: Chemical speciation and biological availability of copper in lake water. Schweiz. Z. Hydrol. 4I, 285-308 (1979).

4 Barlett, L., and Raber, R. W.: Effects of copper, zink and cadmium on Selenastrum capricornutum. Water Res. 8, 179-185 (1974).

5 Bossard, P.: MELIMEX, an experimental heavy metal pollution study: Effects of increased heavy metal concentrations on uptake of glucose by natural planktonic communities. Schweiz. Z. Hydrol 41, 261-270 (1979). 
6 Burnison, G., Wong, P.T.S., Chau, Y.K., and Silverberg, B.: Toxicity of cadmium to freshwater algae. Proceeding of 18 th Annual Meeting of Can. Fed. Biol. Soc. Winnipeg, Manitoba, 1975.

7 Dayton, L., and Lewin, R.A.: The effects of lead on algae. Arch. Hydrobiol., suppl. 49, 25-36 (1975).

8 Erikson, S.J., Lackie, N., and Maloney, T.E.: A Screening Technique for Estimating Copper Toxicity to Marine Phytoplankton. J. WPCF 42, R 270-278 (1970).

9 Gächter, R.: Untersuchungen über die Beeinflussung der planktischen Photosynthese durch anorganische Metallsalze im eutrophen Alpnachersee und der mesotrophen Horwerbucht. Schweiz. Z. Hydrol. 38, 97-119 (1976).

10 Gächter, R., Davis, J.S., and Máreš, A.: Regulation of copper availability to phytoplankton by macromolecules in lake water. Envir. Sci. technol. 12, 1416-1421 (1978).

11 Gächter, R.: Phosphorhaushalt und planktische Primärproduktion im Vierwaldstättersee (Horwer Bucht). Schweiz. Z. Hydrol. 30, 1-66 (1968).

12 Gächter, R., and Máreš, A.: Comments to the acidification and bubbling method for determining phytoplankton production. Oikos 33, 69-73 (1979).

13 Gächter, R.: MELIMEX, an experimental heavy metal pollution study: Goals, experimental design and major findings. Schweiz. Z. Hydrol. 41, 168-171 (1979).

14 Gächter, R., and Geiger, W.: MELIMEX, an experimental heavy metal pollution study: Behaviour of heavy metals in an aquatic food chain. Schweiz. Z. Hydrol. 41, 277-280 (1979).

15 Gibson, C.E.: The algicidal effect of copper on a green and blue-green alga and some ecological implications. J. appl. Ecol. 9, 513-518 (1972).

16 Grice, G. A., Reeve, M.R., Koeller, P., and Menzel, D.W.: The use of large volume, transparent, endorsed sea-surface water column in the study of stress on plankton ecosystems. Helgoländer wiss. Meeresunters. 30, 118-133 (1977).

17 Horne, A., and Goldmann, C.R.: Suppression of nitrogen fixation by blue-green algae in an eutrophic lake with trace additions of copper. Science 183, 409-411 (1973).

18 Jackson, G.A., and Morgan, J.J.: Trace metal-chelator interactions and phytoplankton growth in seawater media: Theoretical analysis and comparison with reported observations. Limnol. Occanogr. 23, 268-295 (1978).

19 Imboden, D., Eid, B., Joller, T., Schurter, M., and Wetzel, J.: MELIMEX, an experimental heavy metal pollution study: Vertical mixing in a large limno-corral. Schweiz. Z. Hydrol. 41,177-189 (1979).

20 Kayser, H.: Effect of zink sulfate on the growth of mono- and multispecies cultures in some marine plankton algae. Helgoländer wiss. Meeresunters. 30, 682-696 (1977).

21 Kuiper, J.: An experimental approach in studying the influence of mercury on North Sea costal plankton community. Helgoländer wiss. Meeresunters. 30, 652-665 (1977).

22 Lang, C., and Lang-Dobler, B.: MELIMEX, an experimental heavy metal pollution study: Oligochaetes and chironomid larvae in heavy metal loaded and control limno-corrals. Schweiz. Z. Hydrol. 41, 271-276 (1979).

23 Leidner, H.A.: Freie und gebundene, gelöste Aminosäuren in einem mit Schwermetallen belasteten und einem (unbelasteten) Kontroll-Modellsee. Not published.

24 Mandelli, E.F.: The inhibitory effects of copper on marine phytoplankton. Contr. mar. Sci. 14, 4757 (1969).

25 Margalef, R.: Ecological correlations and the relationship between primary productivity and community structure. Memorie Ist. ital. Idrobiol. 18, suppl., 355-364 (1965).

26 Pietiläinen, K.: Synergistic and antagonistic effects of lead and cadmium on aquatic primary production. Proceedings of International Conference on Heavy Metals in the Environment, Toronto, Ont. p. 861-874 (1975).

27 Schiess, T.: Limnologisch-Fischereibiologischer Bericht über den Baldeggersee 1974/1975, p. 119 (1976). Not published.

28 Schindler, D.W., Schmidt, R.V., and Reid, R.A.: Acidification and bubbling as an alternative to filtration in determining phytoplankton production by the ${ }^{14} \mathrm{C}$ method. J. Fish. Res. Bd Can. 29, 1627-1631 (1972).

29 SCOR-Unesco: Determination of photosynthetic pigments in seawater. Monographs on oceanographic methodology, No. 1, p.69, Paris 1966.

30 Shannon, C.E., and Wiener, W.: The mathematical theory of communication, $125 \mathrm{p}$. University of Illinois Press, 1963. 
31 Sunda, W., and Guillard, R.R. L.: The relationship between cupric ion activity and the toxicity of copper to phytoplankton. J. mar. Res. 34, 511-521 (1976).

32 Steemann Nielsen, E., and Bruun Laursen, H.: Effects of $\mathrm{CuSO}_{4}$ on photosynthetic rate of phytoplankton in four Danish lakes. Oikos 27, 239-242 (1976).

33 Steemann Nielsen, E., and Wium-Andersen, S.: Copper ions as poison in sea and freshwater. Mar. Biol. 6, 93-97 (1970).

34 Stockes, P.M., Hutchinson, T.C., and Krauter, K.: Heavy metal tolerance in algae isolated from contaminated lakes near Sudbury, Ontario. Can. J. Bat. 51, 2155-2160 (1973).

35 Thomas, W.H., and Seibert, D.L.R.: Effects of copper on the dominance and diversity of algae: controlled ecosystem pollution experiment. Bull. mar. Sci. 27, 23-33 (1977).

36 Thomas, W.H., Seibert, D.L.R., and Takahashi M.: Controlled ecosystem pollution experiment: Effects of mercury on enclosed water columns. III. Phytoplankton population dynamics and production. Mar. Sci. Commun. 3, 331-354 (1977).

37 Thomas, W.H., Holm-Hanse, O., Seibert, D.L.R., Azan, F., Hodson, R., and Takahashi, M.: Effects of copper on phytoplankton standing crop and productivity: Controlled ecosystem pollution experiment. Bull. mar. Sci. 27, 34-43 (1977).

38 Urech, J.: MELIMEX, an experimental heavy metal pollution study: Effects of increased heavy metal loads on crustacea plankton. Schweiz. Z. Hydrol. 41, 247-260 (1979).

39 Wong, P.T.S., Chau, Y.K., and Luxon, P.L.: Toxicity of a mixture of metals on freshwater algae. J. Fish. Res. Bd Can. 35, 479-481 (1978).

40 Wuhrmann, K., and Eichenberger, E.: Experiments on the effects of inorganic enrichment of rivers on periphyton primary production. Verh. int. Ver. Limnol. 19, 2028-2034 (1975).

Address of the authors: Dr. R. Gächter, A. Máreš, Seenforschungslaboratorium EAWAG/ETH, CH6047 Kastanienbaum, Switzerland. 